\title{
Postprandial Glucose Control in Type 1 Diabetes: Importance of the Gastric Emptying Rate
}

\author{
Roberta Lupoli ${ }^{1}$, Federica Pisano ${ }^{2}$ and Brunella Capaldo ${ }^{2, *(\mathbb{C}}$ \\ 1 Department of Molecular Medicine and Medical Biotechnology, Federico II University, 80131 Naples, Italy \\ 2 Department of Clinical Medicine and Surgery, Federico II University, 80131 Naples, Italy \\ * Correspondence: bcapaldo@unina.it; Tel./Fax: +39-081-746-2302
}

Received: 20 June 2019; Accepted: 8 July 2019; Published: 10 July 2019

\begin{abstract}
The achievement of optimal post-prandial (PP) glucose control in patients with type 1 diabetes (T1DM) remains a great challenge. This review summarizes the main factors contributing to PP glucose response and discusses the likely reasons why PP glucose control is rarely achieved in T1DM patients. The macronutrient composition of the meal, the rate of gastric emptying and premeal insulin administration are key factors affecting the PP glucose response in T1DM. Although the use of continuous insulin infusion systems has improved PP glucose control compared to conventional insulin therapy, there is still need for further ameliorations. T1DM patients frequently present a delayed gastric emptying (GE) that produces a lower but more prolonged PP hyperglycemia. In addition, delayed GE is associated with a longer time to reach the glycemic peak, with a consequent mismatch between PP glucose elevation and the timing of premeal insulin action. On this basis, including GE time and meal composition in the algorithms for insulin bolus calculation of the insulin delivery systems could be an important step forward for optimization of PP glucose control in T1DM.
\end{abstract}

Keywords: postprandial glucose; gastric emptying; meal; premeal insulin

\section{Introduction}

A large number of epidemiological and pathophysiological studies have demonstrated that postprandial (PP) hyperglycemia contributes greatly to overall glucose control assessed by $\mathrm{HbA1c}$, and increases the risk of micro- and macrovascular complications in diabetic patients [1-5]. Whether PP hyperglycemia affects cardiovascular (CV) outcomes independently of overall glucose control is still a matter of debate [6]. A great number of clinical and pathophysiological studies have consistently demonstrated that rapid and brisk fluctuations in blood glucose exert harmful effects on the vascular system. [7]. Despite solid clinical and mechanistic evidence, intervention studies evaluating the effects of reducing PP hyperglycemia on CV outcomes in subjects with impaired glucose tolerance or type 2 diabetes have provided contradictory results [8-10]. To date, no long-term intervention study has been performed in T1DM patients. However, clinical studies in T1DM have shown that the endothelial dysfunction and the increased oxidative stress induced by a rapid increase in blood glucose can be reverted through glucose normalization, indirectly confirming the clinical importance of effectively controlling PP hyperglycemia [11]. As a matter of fact, the control of PP hyperglycemia is a recognized important therapeutic goal in the management of diabetes with a target 2-h PP glucose level $<140-180 \mathrm{mg} / \mathrm{dL}$ according to various International Guidelines.

In patients with T1DM, achieving an optimal PP glucose control remains challenging, even if the growing use of continuous glucose monitoring (CGM) systems provides a detailed picture of daily glucose fluctuations, including those occurring in postprandial periods. Indeed, PP hyperglycemia is the result of many interconnected factors, such as the quantity and quality of macronutrients [12], and the characteristics of insulin regimen [13]; all of which affect both the extent and timing of PP 
glycemic response. An emerging key factor is the gastric emptying (GE) rate [14-21]. According to the literature, approximately $40-50 \%$ of T1DM patients present altered GE, which is known to influence the PP glucose pattern. We have recently demonstrated that young T1DM patients with delayed GE present a different "shape" of post-meal glucose response characterized by a longer time to reach the glycemic peak compared to those with normal GE; this glucose pattern would require appropriate pre-meal insulin adjustments [20]. Individualizing pre-meal insulin administration taking into account the meal characteristics as well as the rate of GE could be an important step forward towards the optimization of PP glycemic control in patients with T1DM. The object of this review is to examine the main determinants of PP glucose control in patients with T1DM, with a specific focus on GE time and its impact on PP glycemia. The therapeutic implications of delayed GE in relation to the management of pre-meal insulin will also be discussed.

\section{Gastric Emptying and Postprandial Glucose Control}

\subsection{Physiology of Gastric Emptying}

GE is known to depend on the coordinated motor activity of the stomach and the upper small intestine, controlled by electrical slow waves generated by the interstitial cells of Cajal. The regulation of this system is complex and hinges on the inhibitory feedback arising from the interaction of nutrients with the small intestine, and the modulation by vagus nerve and gut hormones, namely GLP-1, cholecystokinin, peptide YY and ghrelin [22]. The GE rate is greatly influenced by the composition (solid or liquid), energy, and macronutrient content of the meal. Indeed, GE of solids is characterized by a biphasic pattern: a "lag phase" due to the solids being broken down into smaller particles, followed by a "linear emptying phase" in which GE time is approximately linear. In contrast, GE of liquids begins immediately and is directly proportional to the volume of the stomach content [23]. Also, the calorie content of the meal can influence GE: the increase in meal size and calorie content, with an equal macronutrient composition, significantly slows down GE [24]. As for the macronutrient composition of the meal, there is clear evidence that dietary fibers, fat, proteins and low GI foods tend to slow down GE [25-27] either through their influence on physical and chemical composition of the chyme or through the stimulation of gut hormones [28].

The rate of GE is modulated by acute changes in blood glucose concentrations, since hyperglycemia, even at physiological levels ( $\sim 8 \mathrm{mmol} / \mathrm{L})$ delays GE whereas hypoglycemia is associated with prompt acceleration of GE [29]. These changes have been interpreted as an additional mechanism of glucose regulation, i.e., the entry of glucose into the small intestine is slower in condition of hyperglycemia and accelerated in case of hypoglycemia to rapidly restore normoglycemia. It is also important to underline that the relationship between blood glucose and GE is bidirectional: ambient glycemia influences GE time and, reciprocally, GE rate impacts on PP glucose levels. In healthy subjects, GE is estimated to account for about $35 \%$ of the variance in glycemic response following oral glucose or a carbohydrate (CHO)-rich meal [30].

\subsection{Gastric Emptying and Type 1 Diabetes}

Diabetes is frequently associated with motility dysfunction of the upper gastrointestinal tract [31,32]. Indeed, T1DM patients can present with altered GE, which ranges from delayed GE-with a prevalence of $40-50 \%$ [12,24-31] — to, very occasionally, accelerated GE [33]. This variability is likely due to the heterogeneity of study populations with regard to diabetes duration, presence of chronic complications, and differences in the methods to assess GE. Moreover, the absence of upper gastro-intestinal symptoms can make the recognition of this condition particularly difficult, with consequent underestimation of its prevalence. Several mechanisms are held responsible for GE alterations in T1DM patients, including autonomic neuropathy, changes in gut hormone and neurotransmitter patterns, and fluctuations in blood glucose levels [31]. Autonomic neuropathy has long been recognized as a main cause of altered GE. Indeed, GE dysfunction is itself a manifestation of 
autonomic neuropathy and is frequently associated with other chronic complications of the disease. Indeed, in the DCCT/EDIC and in other cohorts of T1DM patients, $40-50 \%$ of patients showed delayed GE associated with severe retinopathy and cardiovascular autonomic dysfunction [19,34]. However, the relationship between delayed GE time and autonomic dysfunction has not been consistently proven [23,35-39].

We have recently demonstrated the presence of delayed GE in a relevant proportion (36\%) of young T1DM patients without any clinical sign of chronic diabetic complications [20], indicating that an impairment of GE can occur quite early in the natural history of the disease-before clinical signs of complications in other districts become evident. Of note, these patients did not present any alterations in the level of gut peptide hormones, indicating that in T1DM patients the role, if any, of these hormones in the impairment of GE is likely to be marginal [20,40].

It has been widely demonstrated that GE disorders have a major impact on PP glucose concentrations in T1DM patients, in terms of both overall glucose response (area under the curve) $[30,41]$ and magnitude of PP glucose excursions [15,26,33,42]. Using CGM, Parthasarathy et al. showed that a delayed GE was associated with higher glucose concentrations over the entire day [34]. Indeed, mean glucose values over the entire glucose monitoring time was directly associated with insulin dose and longer GE time, and inversely correlated with $\mathrm{CHO}$ consumption. In particular, each $10 \%$ increase in GE time resulted in a $0.7 \%$ increase in mean glucose value. PP glucose profile is particularly unstable in T1DM patients with gastroparesis, who are likely to present a condition of "gastric hypoglycemia" due to a mismatch between exogenous insulin action and the rise in blood glucose [43].

Not only gastroparesis but also mildly delayed GE can affect PP glycemia. In our study, T1DM patients with delayed GE time showed a different "shape" of post-meal glucose response that was characterized by a longer time to reach the glycemic peak compared to T1DM patients with normal GE (the average difference was $27 \mathrm{~min}$ ). Interestingly, glucose peak concentration and PP glucose response did not differ between the two groups; this indicates that GE impacts the timing of post-meal glucose increments, as supported by the direct association between GE time and time-to-peak glucose [20].

Whether the use of prokinetic drugs has beneficial effects on PP glucose response in T1DM patients with delayed GE is not clear. Extant research in patients with gastroparesis demonstrated the potential benefits of prokinetic drugs in accelerating GE and in reducing hypoglycemia due to the mismatch between exogenous insulin and PP glucose levels [22]. No data is available on the efficacy of prokinetic drugs in T1DM patients with mild alterations of GE rate; in the meanwhile, in these patients there is no way to handle PP hyperglycemia other than to adopt the insulin regimen that best matches their PP glucose profile.

\section{Other Factors Influencing Postprandial Glucose Control}

\subsection{Meal Characteristics}

The macronutrient composition of the meal can influence PP glucose response either directly as in the case of $\mathrm{CHO}$, or through the modulation of gastro-intestinal hormones and, hence, their impact on GE $[12,16,44]$. In healthy subjects, the increase in PP glucose depends mainly on the quantity but also on the quality of the ingested $\mathrm{CHO}$; according to their ability to raise glucose levels, foods are classified as high glycemic index (GI) and low GI [45]. This has further evolved to the concept of glycemic load (GL), which considers both GI food and the amount of CHO contained in a given portion [46]. High GI foods are characterized by fast $\mathrm{CHO}$ absorption and a rapid increase in blood glucose, whereas low GI foods, because of their content in fibers, and/or protein, and/or fat, are digested and absorbed more slowly, with a more gradual increase in PP glucose $[47,48]$. In addition, in healthy subjects, both dietary protein and fat tend to lower PP glycemic peak and prolong glycemic excursions, mainly due to the ability of protein to stimulate insulin secretion and the ability of fat to slow down GE [44]. Over recent years, growing attention has been paid to the influence of food order on PP glucose levels; indeed, 
consistent evidence indicates that consuming protein or fat prior to a CHO-rich meal results in a lower glucose response compared to when all macronutrients are consumed together [49].

In patients with T1DM, the CHO content and overall composition of the meal impact on PP glucose levels and, consequently, on the timing and dose of premeal insulin [50,51]. Studies evaluating the effects of GI on PP glycemia in T1DM patients reported significant differences in blood glucose levels, with low GI foods producing lower glycemic response [52,53]. In a long-term (6 months) study, a low GI/ high fiber diet decreased blood glucose levels, $\mathrm{HbA1c}$, and the rate of hypoglycemic events compared to a high GI/low fiber diet with similar macronutrient composition [54]. With regard to the determination of pre-meal insulin dose, several methods have been developed over the years. $\mathrm{CHO}$ counting has for long been a key dietary strategy for improving PP glycemic control; however, since the amount of $\mathrm{CHO}$ alone does not entirely account for PP glycemic response [55], novel insulin dosing algorithms based on more complex parameters have been proposed, such as the GI/GL of the meal [56], the fat and protein content, or the energy content of the portion consumed (Food Insulin Index) [57]. Overall, these methods are proven to improve PP glycemic control and reduce glucose variability, albeit with a non-significant reduction in $\mathrm{HbA1c}$ levels [57].

As in healthy subjects, also in T1DM patients the protein and fat content of the meal affects PP glucose profile. It has been demonstrated that the addition of fat to a meal tends to reduce the initial (2-3 h) glucose response, delaying glucose peak while increasing glucose levels in the late PP phase because of a slower GE [58,59]. In T1DM patients using insulin pump, more insulin was required following a high fat/ high protein meal, with some variation among patients; in addition, an extended, split insulin bolus best achieved PP glucose control [60]. In the context of a closed loop system (CLS), Wolpert et al. found that the addition of $50 \mathrm{~g}$ of fat increased insulin requirement by twofold [61]. More recently, Gingras et al. showed that CLS was able to mitigate late PP hyperglycemia following high fat/high protein meal through a 39\% increase in basal insulin infusion in the 5-h post-meal period [62]. Of course, the complexity of these strategies and their impact on a patient's everyday life should not be overlooked.

It is also interesting to note that the quality of fat influences the glucose response to a high GI meal, with high monounsaturated fat achieving lower glucose levels than saturated fat, as shown in a randomized cross-over study in T1DM patients on insulin pump [63]. The addition of protein to CHO also tends to delay PP glucose peak in T1DM patients [64,65]. Of note, the effect seems to be different when proteins are consumed alone or in addition to $\mathrm{CHO}$; in the absence of $\mathrm{CHO}$, a protein load as high as 75-100 g produces an increase in blood glucose [65]. In summary, in patients with T1DM, the macronutrient composition of the meal greatly influences not only the extent but also the "shape" of the PP glucose profile. Based on these findings, considering the overall macronutrient meal content into the calculation of pre-meal insulin bolus represents a challenge for the new automated insulin delivery systems and is an area of active investigation.

\subsection{Pre-Meal Insulin}

Type, dose, timing and method of insulin administration are important variables affecting PP glucose response. In healthy subjects, PP glycemia rises and reaches the peak at $60 \mathrm{~min}$, hardly exceeds $140 \mathrm{mg} / \mathrm{dL}$, and usually returns to basal values within $2-3 \mathrm{~h}$. Simultaneously, there is a rapid increase in insulin concentration and action, within the first 30-120 min. This synchronized glucose-insulin response is lost in people with T1DM [66]. Thus, a major goal of insulin therapy is to rely on a premeal insulin that better mimics the kinetic of endogenous prandial insulin profile to effectively control PP glucose excursions. Rapid acting insulin analogues (RAIAs), i.e., lispro, aspart and glulisine-when used in basal-bolus regimens-resulted to be superior to regular human insulin in achieving this goal, since they restore insulin levels in a more physiological way $[67,68]$. Indeed, RAIAs induces a faster rise in plasma concentration, a higher peak concentration and a shorter subcutaneous residence time, which results in reduced PP glucose excursions and a lower risk of late hypoglycemia compared to regular human insulin $[69,70]$. However, the pharmacokinetic profile of RAIAs is still far from ideal, 
since the duration of subcutaneous absorption does not reproduce the prompt physiological increase in circulating insulin. This limit has been partially overcome by the recently developed fast-acting insulin aspart $[67,68,71]$, a new insulin formulation characterized by faster subcutaneous absorption, faster onset of appearance into the bloodstream, and a 75\% greater early glucose lowering effect than conventional aspart analogue $[67,71,72]$. The ONSET 1 registration trial and other clinical studies have shown the superiority of faster aspart in reducing PP glucose excursions $(21 \mathrm{mg} / \mathrm{dL}$ at $1 \mathrm{~h}$ and $12 \mathrm{mg} / \mathrm{dL}$ at $2 \mathrm{~h}$ ) and $\mathrm{HbA1c}$ levels compared to insulin aspart [73]. Despite the improvements achieved with the new insulin formulations, multiple daily injection therapy does not allow variations in the speed or duration of prandial insulin delivery [74]. Greater flexibility is guaranteed by the insulin pump therapy, which enables to modify prandial insulin delivery according to the composition of the meal so as to mitigate PP glucose excursions [75]. Several studies have evaluated PP glucose response following meals with different composition and different types of insulin boluses (single/quick bolus, two/split bolus, square wave bolus, dual wave bolus) [76-79]. Among the different types of boluses, the dual wave bolus is to be preferred for low GI meals and/or meals with a high fat content. In fact, the 3-h area under the curve (AUC) is lower with the use of double-wave bolus compared to the other types of boluses since it provides a better coverage of prolonged hyperglycemia. In contrast, high GI meals are associated with significant and prolonged upward PP glucose levels, regardless of premeal bolus type $[74,77]$. Although insulin pump therapy represents a remarkable advance in diabetes treatment, patients still struggle to achieve optimal overall and PP glycemic control, with a substantial number of patients presenting $\mathrm{HbA} 1 \mathrm{c}>8.0 \%$ [80]. A further step has been taken with closed-loop automated insulin delivery systems (CLS), in which insulin infusion is regulated by an algorithm based on CGM systems. Compared with conventional insulin pump therapy, CLS have been shown to improve overall glucose control although PP glucose excursions still remain a challenge [81-83], suggesting that other factors contribute to PP glucose profile.

\section{Clinical Impact of Delayed Gastric Emptying and Therapeutic Implications}

Achieving an optimal PP glucose control in T1DM patients remains a clinical challenge, despite the availability of more advanced insulin delivery systems and innovations in glucose sensing technologies having improved PP glucose control. In optimizing PP glucose control, it is worth measuring GE time since the rate at which carbohydrates are delivered to and absorbed by the small intestine affects the PP blood glucose profile. The finding that GE is delayed in a relevant proportion of young asymptomatic T1DM patients and that it impacts the magnitude and the "shape" of PP glycemic response has important implications for the management of pre-prandial insulin; in fact, a delayed GE can result in a mismatch between PP glucose elevation and the timing of insulin action, with consequent high variability in PP glucose profile and, possibly, increased risk of hypoglycemia. Along this line, we propose that GE assessment be included among the screening tests of diabetic complications. The availability of a non-invasive, validated, reproducible and inexpensive method, such as the ${ }^{13} \mathrm{C}$-octanoate breath test, would make the assessment of GE feasible and affordable in clinical practice $[36,84]$. Measurement of GE would be helpful not only to detect early manifestations of chronic diabetic complications but also guide the choice of pre-meal insulin therapy, thus making a step forward toward "tailoring" premeal insulin administration to patients' characteristics. In patients with delayed GE who practice multiple daily injections, some options could be considered: (1) using regular insulin; (2) administering ultra-short insulin 20-30 min after meal ingestion; (3) splitting the insulin dose into two boluses. In all cases, the use of CGM would be fundamental to assess and compare the efficacy of the various insulin schemes. In patients on insulin pump, GE time could help identify the most suitable type of bolus (single bolus, double wave or square wave). A further step could be to include GE time into predictive algorithms for insulin delivery of the new closed-loop systems. In this context, the longer time to glucose peak associated with delayed GE could be handled through GE-guided temporary increase in basal insulin infusion. Ad hoc clinical studies are necessary to test the feasibility and efficacy of this proposal. The current literature on GE in relation to PP 
glucose regulation in T1DM is quite heterogeneous and too limited to allow a systematic analysis to be performed. Our review, although burdened by the limitation of a nonsystematic approach, has the merit of highlighting the important role of GE in PP hyperglycemia and providing further insight into the understanding and management of PP glucose control in T1DM patients. Studies quantifying the GE rate in relation to meal composition and different insulin delivery systems would provide valuable information to help achieve this goal.

Author Contributions: R.L. and F.P. carried out the reference search, selected papers, and wrote the first draft; B.C. conceived the review and prepared the final version of the manuscript. All Authors approved the final version of the paper.

Funding: No funding has been received for this work. Conflicts of Interest: No conflict of interest was declared.

Conflicts of Interest: The authors declare no conflict of interest.

\section{References}

1. Monnier, L.; Lapinski, H.; Colette, C. Contributions of fasting and postprandial plasma glucose increments to the overall diurnal hyperglycemia of type 2 diabetic patients: Variations with increasing levels of $\mathrm{HbA}(1 \mathrm{c})$. Diabetes Care 2003, 26, 881-885. [CrossRef] [PubMed]

2. Standl, E.; Schnell, O.; Ceriello, A. Postprandial hyperglycemia and glycemic variability: Should we care? Diabetes Care 2011, 34, S120-S127. [CrossRef] [PubMed]

3. Badsbad, S. Impact of postprandial glucose control on diabetes-related complications: How is the evidence evolving? J. Diabetes Complicat. 2016, 30, 374-385. [CrossRef] [PubMed]

4. DECODE Study Group. Glucose tolerance and cardio-vascular mortality: Comparison of fasting and 2-h di-agnostic criteria. Arch. Intern. Med. 2001, 161, 397-405. [CrossRef]

5. Meigs, J.B.; Nathan, D.M.; D'Agostino, R.B.; Wilson, P.W. Fasting and postchallenge glycemia and cardiovascular disease risk: The Framingham Offspring Study. Diabetes Care 2002, 25, 1845-1850. [CrossRef] [PubMed]

6. Ceriello, A. Point: Postprandial glucose levels are a clinically important treatment target. Diabetes Care 2010, 33, 1905-1907. [CrossRef] [PubMed]

7. Ceriello, A. Postprandial hyperglycemia and diabetes complications: Is it time to treat? Diabetes 2005, 54, 1-7. [CrossRef]

8. Chiasson, J.L.; Josse, R.G.; Gomis, R.; Hanefeld, M.; Karasik, A.; Laakso, M. Acarbose treatment and the risk of cardiovascular disease and hypertension in patients with impaired glucose tolerance: The STOP-NIDDM trial. JAMA 2003, 290, 486-494. [CrossRef]

9. Holman, R.R.; Haffner, S.M.; McMurray, J.J.; Bethel, M.A.; Holzhauer, B.; Hua, T.A.; Belenkov, Y.; Boolell, M.; Buse, J.B.; Buckley, B.M.; et al. Effect of nateglinide on the incidence of diabetes and cardiovascular events. N. Engl. J. Med. 2010, 362, 1463-1476.

10. Raz, I.; Ceriello, A.; Wilson, P.W.; Battioui, C.; Su, E.W.; Kerr, L.; Jones, C.A.; Milicevic, Z.; Jacober, S.J. Post hoc subgroup analysis of the HEART2D trial demonstrates lower cardiovascular risk in older patients targeting postprandial versus fasting/premeal glycemia. Diabetes Care 2011, 34, 1511-1513. [CrossRef]

11. Ceriello, A.; Esposito, K.; Ihnat, M.; Thorpe, J.; Giuliano, D. Effect of acute iperglycemia, long-term glycaemic control and insulin on endothelial dysfunction and inflammation in Type 1 diabetic patients with different characteristics. Diabet. Med. 2010, 27, 911-917. [CrossRef] [PubMed]

12. Giacco, R.; Costabile, G.; Riccardi, G. Metabolic effects of dietary carbohydrates: The importance of food digestion. Food Res. Int. 2016, 88, 336-341. [CrossRef]

13. Mathieu, C.; Gillard, P.; Benhalima, K. Insulin analogues in type 1 diabetes mellitus: Getting better all the time. Nat. Rev. Endocrinol. 2017, 13, 385-399. [CrossRef] [PubMed]

14. Phillips, L.K.; Deane, A.M.; Jones, K.L.; Rayner, C.K.; Horowitz, M. Gastric emptying and glycaemia in health and diabetes mellitus. Nat. Rev. Endocrinol. 2015, 11, 112-128. [CrossRef] [PubMed]

15. Rayner, C.K.; Samsom, M.; Jones, K.L.; Horowitz, M. Relationships of upper gastrointestinal motor and sensory function with glycemic control. Diabetes Care 2001, 24, 371-381. [CrossRef] [PubMed]

16. Marathe, C.S.; Rayner, C.K.; Jones, K.L.; Horowitz, M. Relationships between gastric emptying, postprandial glycemia, and incretin hormones. Diabetes Care 2013, 36, 1396-1405. [CrossRef] [PubMed] 
17. O’Donovan, D.G.; Doran, S.; Feinle-Bisset, C.; Jones, K.L.; Meyer, J.H.; Wishart, J.M.; Morris, H.A.; Horowitz, M. Effect of variations in small intestinal glucose delivery on plasma glucose, insulin, and incretin hormones in healthy subjects and type 2 diabetes. J. Clin. Endocrinol. Metab. 2004, 89, 3431-3435. [CrossRef]

18. Samsom, M.; Vermeijden, J.R.; Smout, A.J.; Van Doorn, E.; Roelofs, J.; Van Dam, P.S.; Martens, E.P.; Eelkman-Rooda, S.J.; Van Berge-Henegouwen, G.P. Prevalence of delayed gastric emptying in diabetic patients and relationship to dyspeptic symptoms: A prospective study in unselected diabetic patients. Diabetes Care 2003, 26, 3116-3122. [CrossRef]

19. Bharucha, A.E.; Batey-Schaefer, B.; Cleary, P.A.; Murray, J.A.; Cowie, C.; Lorenzi, G.; Driscoll, M.; Harth, J.; Larkin, M.; Christofi, M.; et al. Delayed gastric emptying is associated with early and long-term hyperglycemia in type 1 diabetes mellitus. Gastroenterology 2015, 149, 330-339. [CrossRef]

20. Lupoli, R.; Creanza, A.; Griffo, E.; Nardone, G.; Rocco, A.; Bozzetto, L.; Annuzzi, G.; Riccardi, G.; Capaldo, B. Gastric emptying impacts the timing of meal glucose peak in subjects with uncomplicated type 1 diabetes. J. Clin. Endocrinol. Metab. 2018, 103, 2269-2276. [CrossRef]

21. Marathe, C.S.; Rayner, C.K.; Wu, T.; Jones, K.L.; Horowitz, M. Gastric Emptying and the Personalized Management of Type 1 Diabetes. J. Clin. Endocrinol. Metab. 2018, 103, 3503-3506. [CrossRef] [PubMed]

22. Stevens, J.E.; Jones, K.L.; Rayner, C.K.; Horowitz, M. Pathophysiology and pharmacotherapy of gastroparesis: Current and future perspectives. Expert Opin. Pharm. 2013, 14, 1171-1186. [CrossRef] [PubMed]

23. De Block, C.E.M.; De Leeuw, I.H.; Pelckmans, P.A.; Van Gaal, L.F. Current concepts in gastric motility in diabetes mellitus. Curr. Diabetes Rev. 2006, 2, 113-130. [CrossRef] [PubMed]

24. Gonlachanvit, S.; Chey, W.D.; Goodman, K.J.; Parkman, H.P. Effect of meal size and test duration on gastric emptying and gastric myoelectrical activity as determined with simultaneous [13C] octanoate breath test and electrogastrography in normal subjects using a muffin meal. Dig. Dis. Sci. 2001, 46, 2643-2650. [CrossRef] [PubMed]

25. Cecil, J.E.; Francis, J.; Read, N.W. Comparison of the effects of a high-fat and high-carbohydrate soup delivered orally and intragastrically on gastric emptying, appetite, and eating behaviour. Physiol. Behav. 1999, 67, 299-306. [CrossRef]

26. Benini, L.; Castellani, G.; Brighenti, F.; Heaton, K.W.; Brentegani, M.T.; Casiraghi, M.C.; Sembenini, C.; Pellegrini, N.; Fioretta, A.; Minniti, G. Gastric emptying of a solid meal is accelerated by the removal of dietary fibre naturally present in food. Gut 1995, 36, 825-830. [CrossRef] [PubMed]

27. Jahan-Mihan, A.; Luhovyy, B.L.; EI Khoury, D.; Anderson, G.H. Dietary proteins as determinants of metabolic and physiologic functions of the gastrointestinal tract. Nutrients 2011, 3, 574-603. [CrossRef]

28. Krishnasamy, S.; Abell, T.L. Diabetic Gastroparesis: Principles and current trends in management. Diabetes Ther. 2018, 9, S1-S42. [CrossRef]

29. Russo, A.; Stevens, J.E.; Chen, R.; Gentilcore, D.; Burnet, R.; Horowitz, M.; Jones, K.L. Insulin-induced hypoglycemia accelerates gastric emptying of solids and liquids in long-standing type 1 diabetes. J. Clin. Endocrinol. Metab. 1996, 90, 4489-4495. [CrossRef]

30. Horowitz, M.; Edelbroek, M.A.; Wishart, J.M.; Straathof, J.W. Relationship between oral glucose tolerance and gastric emptying in normal healthy subjects. Diabetologia 1993, 36, 857-862. [CrossRef]

31. Camilleri, M.; Bharucha, A.E.; Farrugia, G. Epidemiology, mechanisms, and management of diabetic gastroparesis. Clin. Gastroenterol. Hepatol. 2011, 9, 5-12. [CrossRef] [PubMed]

32. Bharucha, A.E.; Camilleri, M.; Forstrom, L.A.; Zinsmeister, A.R. Relationship between clinical features and gastric emptying disturbances in diabetes mellitus. Clin. Endocrinol. 2009, 70, 415-420. [CrossRef] [PubMed]

33. Perano, S.J.; Rayner, C.K.; Kritas, S.; Horowitz, M.; Donaghue, K.; Mpundu-Kaambwa, C.; Giles, L.; Couper, J.J. Gastric Emptying Is More Rapid in Adolescents With Type 1 Diabetes and Impacts on Postprandial Glycemia. J. Clin. Endocrinol. Metab. 2015, 100, 2248-2253. [CrossRef] [PubMed]

34. Parthasarathy, G.; Kudva, Y.C.; Low, P.A.; Camilleri, M.; Basu, A.; Bharucha, A.E. Relationship between Gastric Emptying and Diurnal Glycemic Control in Type 1 Diabetes Mellitus: A Randomized Trial. J. Clin. Endocrinol. Metab. 2017, 1, 398-406. [CrossRef] [PubMed]

35. Horowitz, M.; Maddox, A.F.; Wishart, J.M.; Harding, P.E.; Chatterton, B.E.; Shearman, D.J.C. Relationships between esophageal transit and solid and liquid gastric emptying in diabetes mellitus. Eur. J. Nucl. Med. 1991, 18, 229-234. [CrossRef] [PubMed] 
36. Ziegler, D.; Schadewaldt, P.; Mirza, A.P.; Piolot, R.; Schommartz, B.; Reinhardt, M.; Vosberg, H.; Brosicke, H.; Gries, F.A. [13C] Octanoic acid breath test for noninvasive assessment of gastric emptying in diabetic patients: Validation and relationship to gastric symptoms and cardiovascular autonomic function. Diabetologia 1996, 39, 823-830. [CrossRef] [PubMed]

37. Merio, R.; Festa, A.; Bergmann, H.; Eder, T.; Eibl, N.; Stacher-Janotta, G.; Weber, U.; Budka, C.; Heckenberg, A.; Bauer, P.; et al. Slow gastric emptying in type I diabetes: Relation to autonomic and peripheral neuropathy, blood glucose, and glycemic control. Diabetes Care 1997, 20, 419-423. [CrossRef]

38. Migdalis, L.; Thomaides, T.; Chairopoulos, C.; Kalogeropoulou, C.; Charalabides, J.; Mantzara, F. Changes of gastric emptying rate and gastrin levels are early indicators of autonomic neuropathy in type II diabetic patients. Clin. Auton. Res. 2001, 11, 259-263. [CrossRef]

39. Stacher, G.; Lenglinger, J.; Bergmann, H.; Schneider, C.; Brannath, W.; Festa, A.; Meghdadi, S.; Stacher-Janotta, G. Impaired gastric emptying and altered intragastric meal distribution in diabetes mellitus related to autonomic neuropathy? Dig. Dis. Sci. 2003, 48, 1027-1034. [CrossRef]

40. Salehi, M.; Vahl, T.P.; D'Alessio, D.A. Regulation of islet hormone release and gastric emptying by endogenous glucagon-like peptide 1 after glucose ingestion. J. Clin. Endocrinol. Metab. 2008, 93, 4909-4916. [CrossRef]

41. Jones, K.L.; Horowitz, M.; Wishart, M.J.; Maddox, A.F.; Harding, P.E.; Chatterton, B.E. Relationships between gastric emptying, intragastric meal distribution and blood glucose concentrations in diabetes mellitus. J. Nucl. Med. 1995, 36, 2220-2228. [PubMed]

42. Mourot, J.; Thouvenot, P.; Couet, C.; Antoine, J.M.; Krobicka, A.; Debry, G. Relationship between the rate of gastric emptying and glucose and insulin responses to starchy foods in young healthy adults. Am. J. Clin. Nutr. 1988, 48, 1035-1040. [CrossRef] [PubMed]

43. Horowitz, M.; Jones, K.L.; Rayner, C.K.; Read, N.W. ‘Gastric' hypoglycaemia: An important concept in diabetes management. Neurogastroenterol. Motil. 2006, 18, 405-407. [CrossRef]

44. Moghaddam, E.; Vogt, J.A.; Wolever, T.M. The effects of fat and protein on glycemic responses in nondiabetic humans vary with waist circumference, fasting plasma insulin, and dietary fiber intake. J. Nutr. 2006, 136, 2506-2511. [CrossRef] [PubMed]

45. Englyst, K.N.; Liu, S.; Englyst, H.N. Nutritional characterization and measurement of dietary carbohydrates. Eur. J. Clin. Nutr. 2007, 61, S19-S39. [CrossRef]

46. Brand-Miller, J.C.; Thomas, M.; Swan, V.; Ahmad, Z.I.; Petocz, P.; Colagiuri, S. Physiological validation of the concept of glycemic load in lean young adults. J. Nutr. 2003, 133, 2728-2732. [CrossRef]

47. Brynes, A.E.; Adamson, J.; Dornhorst, A.; Frost, G.S. The beneficial effect of a diet with low glycaemic index on $24 \mathrm{~h}$ glucose profiles in healthy young people as assessed by continuous glucose monitoring. Br. J. Nutr 2005, 93, 179-182. [CrossRef]

48. Tosh, S. Review of human studies investigating the post-prandial blood-glucose lowering ability of oat and barley food products. Eur. J. Clin. Nutr. 2013, 67,310-317. [CrossRef]

49. Nesti, L.; Mengozzi, A.; Tricò, D. Impact of Nutrient Type and Sequence on Glucose Tolerance: Physiological Insights and Therapeutic Implications. Front. Endocrinol. 2019, 10, 144. [CrossRef]

50. Bell, K.J.; King, B.R.; Shafat, A.; Smart, C.E. The relationship between carbohydrate and the mealtime insulin dose in type 1 diabetes. J. Diabetes Complicat. 2015, 29, 1323-1329. [CrossRef]

51. Bell, K.J.; Smart, C.E.; Steil, G.M.; Brand-Miller, J.C.; King, B.; Wolpert, H.A. Impact of fat, protein, and glycemic index on postprandial glucose control in type 1 diabetes: Implications for intensive diabetes management in the continuous glucose monitoring era. Diabetes Care 2015, 38, 1008-1015. [CrossRef] [PubMed]

52. Nansel, T.R.; Gellar, L.; McGill, A. Effect of varying glycemic index meals on blood glucose control assessed with continuous glucose monitoring in youth with type 1 diabetes on basal-bolus insulin regimens. Diabetes Care 2008, 31, 695-697. [CrossRef]

53. Parillo, M.; Annuzzi, G.; Rivellese, A.A.; Bozzetto, L.; Alessandrini, R.; Riccardi, G.; Capaldo, B. Effects of meals with different glycaemic index on postprandial blood glucose response in patients with Type 1 diabetes treated with continuous subcutaneous insulin infusion. Diabet Med. 2011, 28, 227-229. [CrossRef] [PubMed]

54. Giacco, R.; Parillo, M.; Rivellese, A.A.; Lasorella, G.; Giacco, A.; D’Episcopo, L.; Riccardi, G. Long-term dietary treatment with increased amounts of fiber-rich low-glycemic index natural foods improves blood glucose control and reduces the number of hypoglycemic events in type 1 diabetic patients. Diabetes Care 2000, 23, 1461-1466. [CrossRef] [PubMed] 
55. Bell, K.J.; Barclay, A.W.; Petocz, P.; Colagiuri, S.; Brand-Miller, J.C. Efficacy of carbohydrate counting in type 1 diabetes: A systematic review and meta-analysis. Lancet Diabetes Endocrinol. 2014, 2, 133-140. [CrossRef]

56. Bozzetto, L.; Giorgini, M.; Alderisio, A.; Costagliola, L.; Giacco, A.; Riccardi, G.; Rivellese, A.A.; Annuzzi, G. Glycaemic load versus carbohydrate counting for insulin bolus calculation in patients with type 1 diabetes on insulin pump. Acta Diabetolog. 2015, 52, 865-871. [CrossRef] [PubMed]

57. Bell, K.J.; Gray, R.; Munns, D.; Petocz, P.; Steil, G.; Howard, G.; Colagiuri, S.; Brand-Miller, J.C. Clinical Application of the Food Insulin Index for Mealtime Insulin Dosing in Adults with Type 1 Diabetes: A Randomized Controlled Trial. Diabetes Technol. Ther. 2016, 18, 218-225. [CrossRef]

58. Garcia-Lopez, J.M.; Gonzalez-Rodriguez, M.; Pazos-Couselo, M.; Gude, F.; Prieto-Tenreiro, A.; Casanueva, F. Should the amounts of fat and protein be taken into consideration to calculate the lunch prandial insulin bolus? Results from a randomized crossover trial. Diabetes Technol. 2013, 15, 166-171. [CrossRef] [PubMed]

59. Lodefalk, M.; Aman, J.; Bang, P. Effects of fat supplementation on glycaemic response and gastric emptying in adolescents with type 1 diabetes. Diabet Med. 2008, 25, 1030-1035. [CrossRef] [PubMed]

60. Bell, K.J.; Toschi, E.; Steil, G.M.; Wolpert, H.A. Optimized Mealtime Insulin Dosing for Fat and Protein in Type 1 Diabetes: Application of a Model-Based Approach to Derive Insulin Doses for Open-Loop Diabetes Management. Diabetes Care 2016, 39, 1631-1634. [CrossRef]

61. Wolpert, H.A.; Atakov-Castillo, A.; Smith, S.A.; Steil, G.M. Dietary fat acutely increases glucose concentrations and insulin requirements in patients with type 1 diabetes: Implications for carbohydrate-based bolus dose calculation and intensive diabetes management. Diabetes Care 2013, 36, 810-816. [CrossRef]

62. Gingras, V.; Bonato, L.; Messier, V.; Roy-Fleming, A.; Smaoui, M.R.; Ladouceur, M.; Rabasa-Lhoret, R. Impact of macronutrient content of meals on postprandial glucose control in the context of closed-loop insulin delivery: A randomized cross-over study. Diabetes Obes. Metab. 2018, 20, 2695-2699. [CrossRef] [PubMed]

63. Bozzetto, L.; Alderisio, A.; Clemente, G.; Giorgini, M.; Barone, F.; Griffo, E.; Costabile, G.; Vetrani, C.; Cipriano, P.; Giacco, A.; et al. Gastrointestinal effects of extra-virgin olive oil associated with lower postprandial glycemia in type 1 diabetes. Clin. Nutr. 2018. [CrossRef] [PubMed]

64. Smart, C.E.M.; Evans, M.; O'Connell, S.M.; McElduff, P.; Lopez, P.E.; Jones, T.W.; Davis, E.A.; King, B.R. Both dietary protein and fat increase postprandial glucose excursions in children with type 1 diabetes, and the effect is additive. Diabetes Care 2013, 36, 3897-3902. [CrossRef] [PubMed]

65. Paterson, M.A.; Smart, C.E.M.; Lopez, P.E.; Howley, P.; McElduff, P.; Attia, J.; Morbey, C.; King, B.R. Increasing the protein quantity in a meal results in dose-dependent effects on postprandial glucose levels in individuals with Type 1 diabetes mellitus. Diabet Med. 2014, 34, 851-854. [CrossRef] [PubMed]

66. Akturk, H.K.; Rewers, A.; Joseph, H.; Schneider, N.; Garg, S.K. Possible Ways to Improve Postprandial Glucose Control in Type 1 Diabetes. Diabetes Technol. Ther. 2018, 20, 224-232. [CrossRef] [PubMed]

67. Bode, B.W.; Johnson, J.A.; Hyveled, L.; Tamer, S.C.; Demissie, M. Improved Postprandial Glycemic Control with Faster-Acting Insulin Aspart in Patients with Type 1 Diabetes Using Continuous Subcutaneous Insulin Infusion. Diabetes Technol. Ther. 2017, 19, 25-33. [CrossRef] [PubMed]

68. Sharma, A.K.; Taneja, G.; Kumar, A.; Sahu, M.; Sharma, G.; Kumar, A.; Sardana, S.; Deep, A. Insulin analogs: Glimpse on contemporary facts and future prospective. Life Sci. 2019, 15, 90-99. [CrossRef]

69. Home, P.D. The pharmacokinetics and pharmacodynamics of rapid-acting insulin analogues and their clinical consequences. Diabetes Obes. Metab. 2012, 14, 780-788. [CrossRef]

70. Mannucci, E.; Monami, M.; Marchionni, N. Short-acting insulin analogues vs. regular human insulin in type 2 diabetes: A meta-analysis. Diabetes Obes. Metab. 2009, 11, 53-59. [CrossRef]

71. Basu, A.; Pieber, T.R.; Hansen, A.K.; Sach-Friedl, S.; Erichsen, L.; Basu, R.; Haahr, H. Greater early postprandial suppression of endogenous glucose production and higher initial glucose disappearance is achieved with fast-acting insulin aspart compared with insulin aspart. Diabetes Obes. Metab. 2018, 20, 1615-1622. [CrossRef]

72. Heise, T.; Pieber, T.R.; Danne, T.; Erichsen, L.; Haahr, H. A Pooled Analysis of Clinical Pharmacology Trials Investigating the Pharmacokinetic and Pharmacodynamic Characteristics of Fast-Acting Insulin Aspart in Adults with Type 1 Diabetes. Clin. Pharm. 2017, 56, 551-559. [CrossRef] [PubMed]

73. Mathieu, C.; Bode, B.W.; Franek, E.; Philis-Tsimikas, A.; Rose, L.; Graungaard, T.; Birk Østerskov, A.; Russell-Jones, D. Efficacy and safety of fast-acting insulin aspart in comparison with insulin aspart in type 1 diabetes (onset 1): A 52-week, randomized, treat-to-target, phase III trial. Diabetes Obes. Metab. 2018, 20, 1148-1155. [CrossRef] [PubMed] 
74. Regittnig, W.; Urschitz, M.; Lehki, B.; Wolf, M.; Kojzar, H.; Mader, J.K.; Ellmerer, M.; Pieber, T.R. Insulin Bolus Administration in Insulin Pump Therapy: Effect of Bolus Delivery Speed on Insulin Absorption from Subcutaneous Tissue. Diabetes Technol. Ther. 2019, 21, 44-50. [CrossRef] [PubMed]

75. Krzymien, J.; Ladyzynski, P. Insulin in type 1 or type 2 diabetes- shoul the dose of insulin before a meal be based on glycemia or meal content? Nutrients 2019, 11, 607. [CrossRef] [PubMed]

76. Heinemann, L.J. Insulin pump therapy: What is the evidence for using different types of boluses for coverage of prandial insulin requirements? Diabetes Sci. Technol. 2009, 3, 1490-1500. [CrossRef] [PubMed]

77. Chase, H.P.; Saib, S.Z.; MacKenzie, T.; Hansen, M.M.; Garg, S.K. Post-prandial glucose excursions following four methods of bolus insulin administration in subjects with type 1 diabetes. Diabet. Med. 2002, 19, 317-321. [CrossRef]

78. Piechowiak, K.; Dżygało, K.; Szypowska, A. The additional dose of insulin for high-protein mixed meal provides better glycemic control in children with type 1 diabetes on insulin pumps: Randomized cross-over study. Pediatr. Diabetes 2017, 18, 861-868. [CrossRef]

79. O'Connell, M.A.; Gilbertson, H.R.; Donath, S.M.; Cameron, F.J. Optimizing postprandial glycemia in pediatric patients with type 1 diabetes using insulin pump thraepy: Impact of glycemic index and prandial bolus type. Diabetes Care 2008, 31, 1491-1495. [CrossRef]

80. Pickup, J.C. Is insulin pump therapy effective in Type 1 diabetes? Diabet. Med. 2019, 36, 69-278. [CrossRef]

81. Gingras, V.; Taleb, N.; Roy-Fleming, A.; Legault, L.; Rabasa-Lhoret, R. The challenges of achieving postprandial glucose control using closed-loop systems in patients with type 1 diabetes. Diabetes Obes. Metab. 2018, 20, 245-256. [CrossRef]

82. Sánchez, O.D.; Ruiz-Velázquez, E.; Alanís, A.Y.; Quiroz, G.; Torres-Treviño, L. Parameter estimation of a meal glucose-insulin model for TIDM patients from therapy historical data. IET Syst. Biol. 2019, 13, 8-15. [CrossRef] [PubMed]

83. Herrero, P.; Bondia, J.; Adewuyi, O.; Pesl, P.; El-Sharkawy, M.; Reddy, M.; Toumazou, C.; Oliver, N.; Georgiou, P. Enhancing automatic closed-loop glucose control in type 1 diabetes with an adaptive meal bolus calculator-In silico evaluation under intra-day variability. Comput. Methods Progr. Biomed. 2017, 146, 125-131. [CrossRef] [PubMed]

84. Sanaka, M.; Nakada, K.; Nosaka, C.; Kuyama, Y. The Wagner-Nelson method makes the [13C]-breath test comparable to radioscintigraphy in measuring gastric emptying of a solid/liquid mixed meal in humans. Clin. Exp. Pharm. Physiol. 2007, 34, 641-644. [CrossRef] [PubMed] 